\author{
KAMILA ZIÓtKOWSKA-WEISS \\ Uniwersytet Pedagogiczny w Krakowie, Polska - Pedagogical University of Krakow, Poland \\ EMILIA PIERON \\ Uniwersytet Pedagogiczny w Krakowie, Polska - Pedagogical University of Krakow, Poland
}

\title{
Assessment of the impact of terrorism on tourism in the 21st century: the example of Egypt
}

\begin{abstract}
The article aims to analyse the impact of terrorism in Egypt on its tourism sector. To investigate the topic and obtain an answer to the research thesis that terrorism threat affects the level of tourism in Egypt, a literature review was used, and research was carried out in the form of an online questionnaire. The concept of terrorism is defined, and its types, causes and characteristics are shown through specific examples. The research has shown that terrorist threats perceived by tourists have a significant impact on their decisions when choosing a tourist destination. It shows that $36 \%$ of the respondents checked the current political situation of the chosen destination long before the planned departure, and $55 \%$ did it shortly before leaving.
\end{abstract}

Keywords: Arab countries; Egypt; terrorism; tourism

Received: 27 October 2020

Accepted: 6 May 2021

Suggested citation:

Ziółkowska-Weiss, K., Pieron, E. (2021). Assessment of the impact of terrorism on tourism in the 21st century: the example of Egypt. Przedsiębiorczość - Edukacja [Entrepreneurship - Education], 17(1), 244-256. https://doi.org/10.24917/20833296.171.19

\section{Introduction}

Armed conflicts and terrorism are undoubtedly a scourge of the modern world. Tourism is very sensitive to any tension, let alone more frequent manifestations of violence in some parts of the world. Tourism in such places decreases and, consequently, the income it produces is limited. Travel agencies, brokers, agents, managers of accommodation and catering facilities, carriers, pilots and guides, sellers and producers of souvenirs, and many other groups operating in the tourism business suffer in such a situation. Tourists, however, can lose time, money, and sometimes, what is most valuable, health or even life. States with a tourism monoculture are most susceptible to the adverse effects of terrorist 
attacks. Tourists cannot predict a terrorist attack, nor do they know where and when a new armed conflict will break out. However, they can minimise the risk of a dangerous situation by analysing the materials available on this subject. This is also the role of tourist offices expected to provide reliable information about existing threats and armed conflicts in a tourist destination selected by the consumer.

The Egyptian tourism industry, accounting for $1 \%$ of the global tourism market, is one of the most important sectors of its national economy. However, constant political instability causes fluctuations in the income from tourism. While tourists may avoid risk-related sites, the consequences of catastrophic events at tourist destinations are inevitable. Tourism-oriented terrorism can be seen as a disaster for a destination, and related events can cause severe tourism and economic crisis, as is the case in Egypt. Destinations, especially those exposed to politically motivated violence, should incorporate crisis management planning into their overall sustainability strategy and marketing and management. It is needed to protect and restore an image of security and attractiveness, assure potential visitors of the area's safety, restore functionality and help travellers and the tourism industry revitalise the economy.

The article deals with security and threats resulting from terrorist attacks. Empirical research, which took the form of an online questionnaire, was aimed at showing what criteria Polish tourists take into account when choosing a holiday destination, whether the political situation and risk to safety will be critical, and what factors, according to the respondents, affect the sense of security or lack of it during tourist trips, in this case to Egypt.

\section{Terrorism as an asymmetric threat to the modern world}

Modern terrorism, which emerged in the second half of the 20th century, has become one of the scourges of the modern world. Some authors believe that terrorism will increase in the future and that terrorist acts will be more successful. In turn, however, other academics believe that terrorism is coming to an end. Political violence and terrorism may seem to be a set of unknown, intentional and unintentional distortions to the tourism market. Both the state and terrorist groups do a lot to distort in their favour social and individual perceptions of terrorism, manipulating both the semantic content of the concept and specific facts. The media has some influence on the distortion of the actual image of terrorism as well. In addition, the very specificity of the subject makes it difficult to understand, and researchers are doomed to the necessity of making assumptions and interpreting available information, which sometimes has doubtful reliability.

The scope of terrorist activities and the modernisation of their methods of operation has been possible thanks to progressive development in the field of information technology and telecommunications. Terrorism has become a method of political struggle. At the same time, it is a kind of 'asymmetric threat' generated by specific social, ethnic and religious groups while it is perceived as an instrument of the foreign policy of many countries (Nizioł-Celewicz, 2006).

Today, terrorism is a common phenomenon. However, the term is not always used appropriately. Increasingly, it is defined as any violent action directed against society, even if it is backed by criminals, political dissidents or religious fanatics. Terrorism is just as often misinterpreted as economic extortion for reasons utterly different from those of the terrorists themselves (Aleksandrowicz, 2008). 
Quite an important event in the history of Islamic terrorism was the creation of the Muslim Brotherhood in 1928. The ideas promoted by the Brotherhood are almost identical to those of Islamic fundamentalists, and the importance of this group stems from its members establishing many important terrorist organisations. Examples include Hamas and Jamaa Islamiya (Kuczyński, 2001).

In the 1940s and 1950s, there was an increase in anti-colonial and national liberation terrorism in the Middle East, Asia and Africa. In the 1950s and early 1960s, there was an increase in separatist, right-wing and national liberation groups. Organisations such as the PLO and the Kurdistan Workers' Party operated in India, Indonesia and the Middle East, while in Algeria, the far-right groups of the National Liberation Front were active. The organisations fighting for the independence of Cyprus operated mainly in Greece. Many terrorist groups were active in France, among others the far-right Gaullist militias, the Corsican Liberation Front, Algerian groups, the Secret Military Organisation OAS (Organization de l'Armée Secrète). The area of operation of extreme-right groups such as the New Order (Ordine Nuovo), Mussolini Action Units (Squadre d'Azione Mussolini), and the Rose of the Winds (La Rosa dei Venti) was the state of Italy. Terrorist organisations were also active in countries such as the United Kingdom (IRA), Canada (Quebec Liberation Front) and the United States of America (KKK, Black Panthers) (Pospiszyl, 2008).

The classification proposed by D.C. Rapoport (2004) distinguishes four overlapping waves, or stages, of terrorism. The first is dated from 1879, with its end associated with the beginning of the First World War. This phase was characterised mainly by the propagation of terrorist ideas by anarchists and nationalists and by causing revolutions and crises in great empires such as the Ottoman, Habsburg and Russian. The second stage covers the period from the First World War to several years after the Second. At that time, terrorists mainly preached ideas of self-determination and decolonisation. The next wave lasted from the second half of the 1960s to the 1990s, characterised by the promotion of leftist and nationalist ideas and terrorism in the Cold War. The fourth stage has lasted from 1979 until today and is referred to as the religious era of jihad based mainly on religious and anti-globalisation motives (Wojciechowski, 2011).

The network organisation model is characteristic of contemporary Islamic terrorist organisations. Groups such as Hamas, the Palestinian Islamic Jihad and Al Qaeda have a "flattened", poorly hierarchical and informal structure with an ideological centre but no decision-making. They function on the principle of concentric circles. At the centre is the "core" of professionals (for example, veterans of the war in Afghanistan). Another segment is a network of independent cells created by "amateurs" who carry out specific actions. Outside, there are groups of entities cooperating with the organisation but not a part of it (e.g. companies enabling the laundering of "dirty" money) (Nizioł-Celewicz, 2006).

A feature of today's Islamist organisations is the use of the latest technology, especially in information and communication. This raises concerns about the risk of cyberterrorism that is associated with using the technological revolution for new forms of attack. The only difficulty may be that IT skills and the chance to cause fatalities are lacking (Nizioł-Celewicz, 2006). 
The purpose and timing of empirical research

The research aimed to show the impact of terrorism in Arab countries on the tourism of the 21st century in Egypt. The research thesis put forward was that terrorist threats in Arab countries significantly affect Egypt's level of tourism. In order to confirm the hypothesis, an online questionnaire was undertaken among those aged 18 and over, and 100 people responded. This study aimed to show a relationship between terrorism and the choice of Egypt (a country affected by this phenomenon) as a tourist destination.

The questionnaire was made available to respondents via the website survio.com and was conducted from March to May 2019. Surveys are one of the most common forms of social research. Initially, the researched group was determined, then a questionnaire was constructed with questions to verify the research thesis. The next task was to conduct the research, and after obtaining the planned number of responses, an analysis was carried out. The survey questionnaire consisted of 17 single-choice closed questions, four of which concerned the characteristics of the researched group. Only selected results of the research will be presented in this work.

Analysis of respondents' perception of the impact of terrorism on tourism in the 21st century based on the example of Egypt

Apart from the questions concerning the perception of the impact of terrorism on tourism in Egypt, there were also those about the respondents' tourism, their choice of destination, length of stay and participation in optional trips. Analysis of these questions was omitted as the author focused on analysing questions related to terrorism and the assessment of security. The questions were formulated in such a way as to find out the opinions of the respondents on the impact of terrorism.

One hundred respondents replied: 59 women (59\%) and 41 men (41\%). The questionnaire was addressed to five age groups:

- 18-25 years old (schoolchildren, students),

- 26-35 years old (those at the last stage of education and starting their own families),

- 36-45 years old (those of reproductive age, trying to achieve personally),

- 46-60 years old (those beyond the reproductive age with families and achieved goals),

- over 60 (pensioners).

Among those who took part in the survey, 20\% were aged 18-25, 23\% aged 26-35, $19 \%$ aged $36-45,22 \%$ aged $46-60$, and $16 \%$ of respondents were aged over 60 .

The respondents were asked whether the political situation, including the security of the destination of travel/leisure, influenced their choice of a tourist destination (Figure 1).

When asked whether the political situation and hence the security of a given country influenced the respondents' choice of tourist destination, as many as $87 \%$ gave an affirmative answer, and $6 \%$ denied it for $7 \%$ of the respondents it did not matter.

In the questionnaire, the respondents were asked whether they kept up to date with the current political situation of their chosen destination before departure (Figure 2).

Out of all those who answered this question, 55\% replied that shortly before leaving they checked the political situation in the country where they had planned their holiday, $36 \%$ of them follow the information on this subject for an extended period before the 
planned trip. In comparison, $9 \%$ say that they are not interested in news of this type and do not check the current situation in the country of their destination before leaving.

In one of the questions, the respondents were able to express their opinion on the level of security in Egypt. They could mark their feelings on a scale of 1 to 10, where 1 was the lowest and 10 the highest (Figure 3).

Respondents had the opportunity to rate their assessment of the security level in Egypt on a scale of 1 to 10 . Security at Levels 1 and 2, as well as 9 and 10, was identified by $3 \%$ of respondents. Security at Level 3 by $13 \%$ and at 4 by $12 \%$. At Level 5, the highest percentage of respondents was found $-32 \%$, at Level 6 , it was $12 \%$, but Level 8 - only $6 \%$. The graph above shows that the highest percentages were obtained for Levels 3 to 6 , which means that more than half of the respondents chose them. Therefore, according to the respondents, the political and security situation in Egypt is at a moderate to good level.

The author asked the respondents whether, in their opinion, the authorities of a destination country should be interested in the terrorist threat issue (Figure 4).

$96 \%$ of respondents believe that the problem of a terrorist threat is severe and the authorities of a given country should pay attention to it. Only $4 \%$ are of a different opinion. Respondents were also asked where they got information about threats in the Middle East (Figure 5).

The most important source of information on threats in the Middle East is the internet. Such an answer was given by as many as $68 \%$ of the respondents, $30 \%$ obtain such information from radio or television, and only $2 \%$ from friends, family or other people. None of the respondents found this type of information from newspapers and magazines. Based on this question, we can see the technological power of the internet and how the daily and once-popular sources of information, such as newspapers, have been superseded in the era of digitalisation.

Figure 1. Does the political situation, including national security, affect your choice of a travel/ leisure destination?

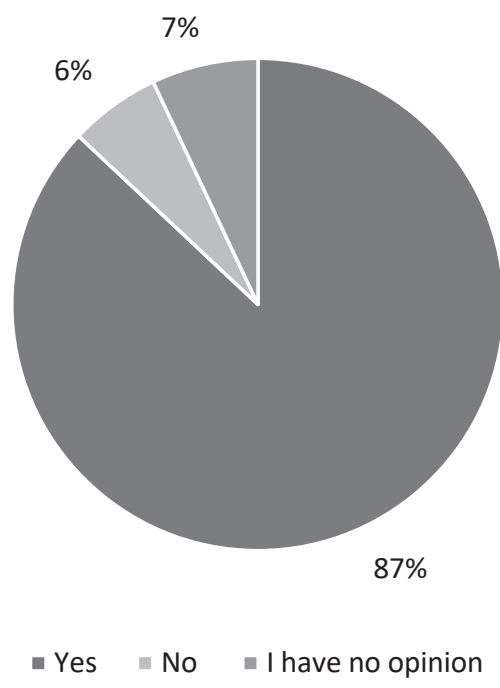

Source: author based on empirical research 
Figure 2. Before leaving, do you keep track of the current political situation of your chosen destination?

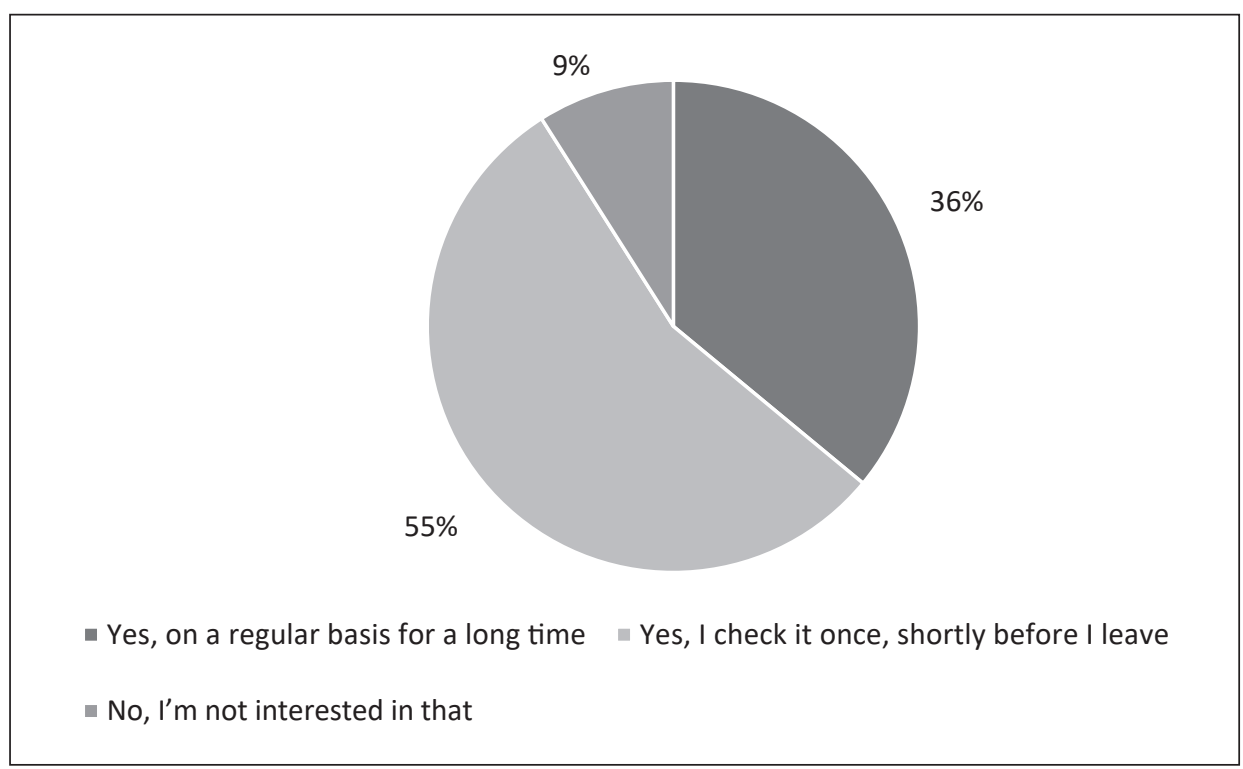

Source: author based on empirical research

Figure 3. Assessment of the security level in Egypt (scale 1-10)

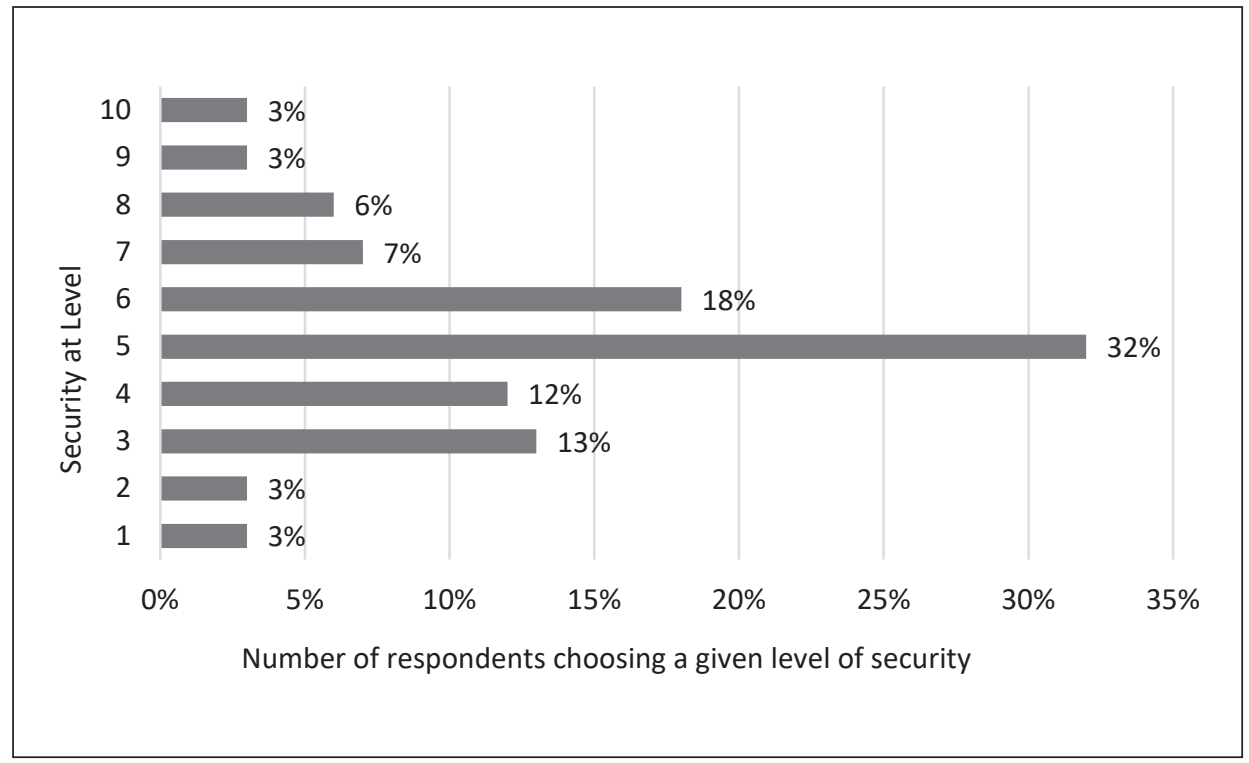

Source: author based on empirical research 
Figure 4. Do you think the authorities of a destination country should be interested in the terrorist threat issue?

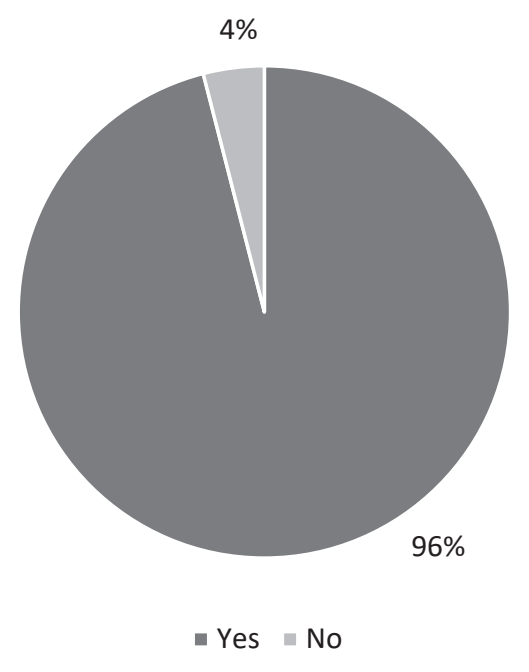

Figure 5 . Where do you get most information about the threats?

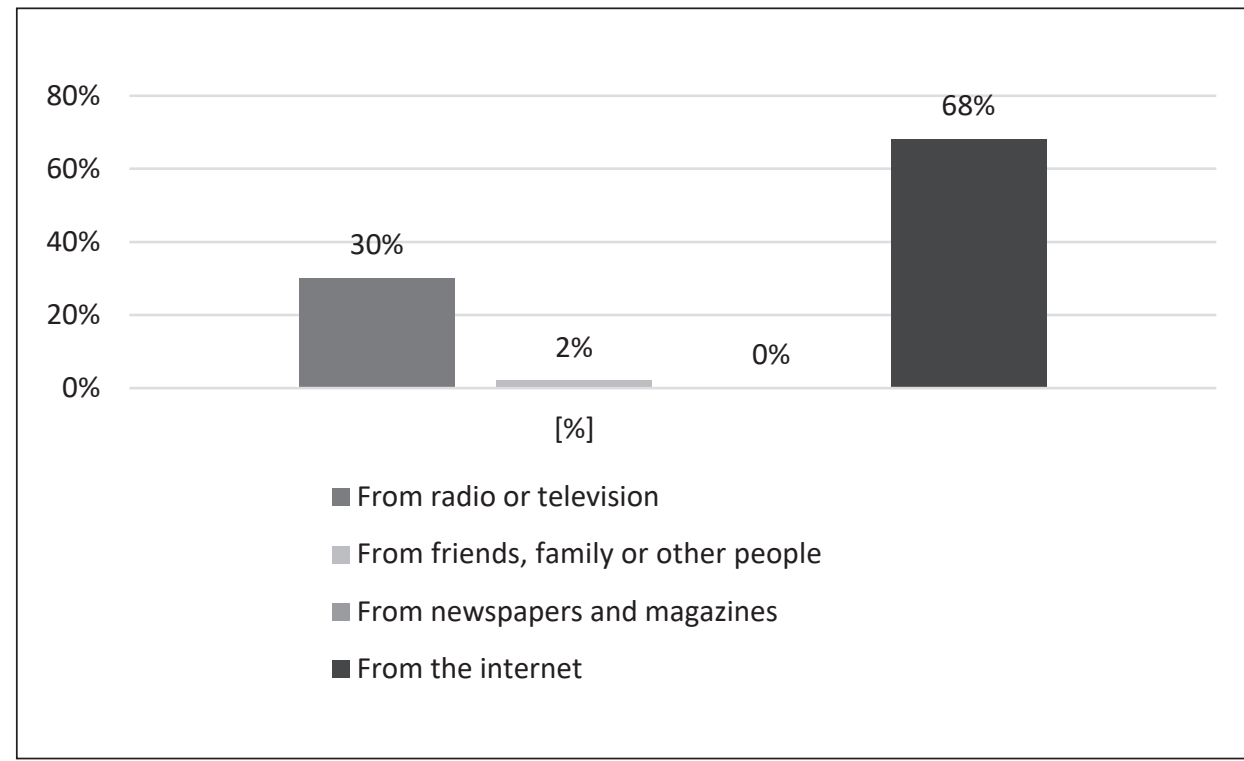

Source: author based on empirical research 
Figure 6. In your opinion, does the media increase the sense of danger in Egypt?

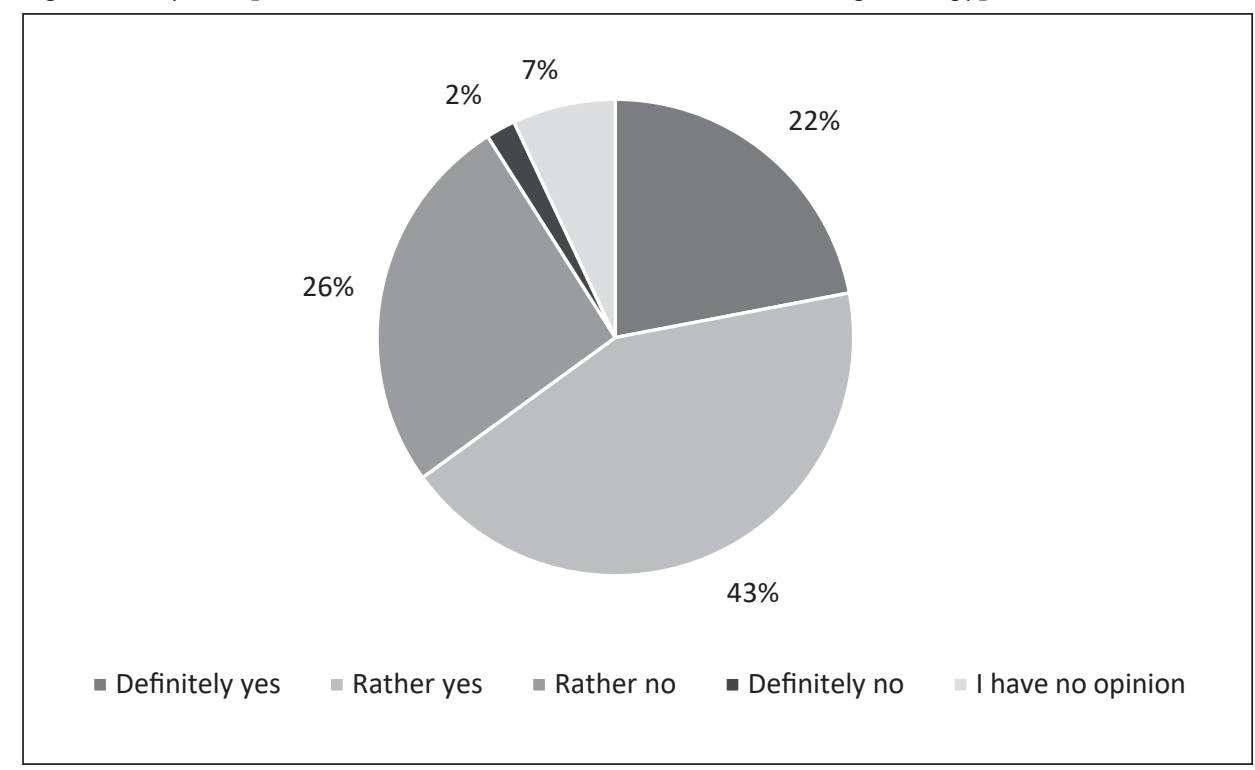

Source: author based on empirical research

One of the questions was about the increase in the sense of threat in Egypt evoked by the media (Figure 6).

$43 \%$ of respondents believe that the media intensifies the feeling of danger in Egypt, while $22 \%$ indicate that the media promotes such a feeling. According to $26 \%$, it is not intensified, and $2 \%$ that it definitely does not exaggerate the problem. $7 \%$ do not have an opinion on this matter.

\section{Discussion}

The hypothesis put forward in this work that terrorist threats in Arab countries significantly affect the level of tourism in Egypt among Polish tourists is not valid. Indeed, $96 \%$ of respondents believe that the threat of terrorism today is profound and worth the attention of the authorities of a given country and international security organisations. As many as $55 \%$ of respondents check the current political situation of the chosen destination once shortly before departure, but $36 \%$ follow it regularly from a long time before. However, the activities undertaken by the respondents do not mean that they do not choose Egypt as their tourist destination.

There is a study of the relationship between terrorism and the demand for tourism in Egypt by S. Polyzos, G. Papadopoulou, S. Xesfingi (2021) who studied the relationship between tourism demand and terrorism in Egypt based on monthly data for 1995-2018. They aimed to investigate whether this relationship is one-way or two-way, and durable in the long term. The researchers found evidence of a long-term relation between tourism and terrorism. Their empirical results showed a strong correlation between fear of terrorism and tourism in Egypt and concluded that policymakers should not expect an increase in terrorist activity in times of an increased influx of tourists. They argued that 
the authorities should enforce stringent anti-terrorism measures to promote security and safety in the context of tourism in Egypt.

A. Pizam, G. Smith (2000), in the article Tourism and Terrorism: A Historical Analysis of Major Terrorism Acts and their Impact on Tourism Destinations, made a quantitative analysis of the most critical terrorist events around the world in 1985-1998, classifying them by date, location, victims, weapons used, the severity of the damage, the motive, and the impact on the demand for tourism. Their research found that terrorist attacks are more common in tourist destinations where the number of foreign tourists is large. Over the 14 years of the study period, they identified 70 terrorist attacks, most of which were in the Middle East, including Egypt. These acts killed 830 people and injured 1465. Most of the injured were tourists. Regarding the impact of these actions on tourism demand, Pizam and Smith (2000) showed it decreased by $79 \%$ compared to previous years when there were no acts of terrorism. The decline in tourism demand lasted from one to six months. The research also showed that both individual tourists and travel agencies postponed their trips for up to six months from acts of terrorism at the tourist reception location.

D. Fielding and A. Shortland (2010), in the article How do tourists react to political violence? An empirical analysis of tourism in Egypt, described a model that concerns those who decided to go on holiday anyway. As their research showed, the factor of security and terrorist threats did not play a significant role among their respondents.

Y.H. Aly and M.C. Strazicich (2000) presented research covering the 1990s, starting in March 1991 and ending in December 2000, which showed that the campaign of radical Islamist organisations was successful in inflicting heavy losses on the Egyptian tourism industry. Although the real danger of an attack was minimal, many tourists decided not to consider Egypt when planning holidays. Their research has shown that attacks at tourist facilities where foreigners have been killed or injured have immediate resonance in tourist bookings and destination selection. This state of affairs lasts more than a year before the number of tourists visiting the place affected by a terrorist attack fully returns to the state it was before the event.

R. Isaac (2021), on the other hand, presented research aimed at better understanding the impact of terrorism on the perception of risk and the attitudes of German travellers to Egypt. The research process included an online self-administered method using Qualtrics, one of the leading research and web tools. One hundred seventy-one respondents completed the questionnaire, and the results indicated that Egypt is viewed as a dangerous travel destination. It argued that the Egyptian government should create a more attractive image for Egypt as a holiday location.

After the revolution in 2011, tourism in Egypt decreased significantly related to the unstable situation in the country and the anxiety of tourists. The situation slowly stabilised after the parliamentary elections in 2012 (Marciniak, Dłużewska, 2015). That year, Egypt was visited by over 750000 tourists, but by July 2013, the tourism sector had decreased by $24.5 \%$ compared to the previous year. This situation was related to the deepening chaos in Egypt, demonstrations against President Morsi and the revolution that led to military rule in the country. Clashes between supporters and opponents of the Muslim Brotherhood contributed to a decline in tourism by $69.7 \%$.

According to D.S. Abdou and Z. Zaazou (2013), tourism felt the adverse effects of the Arab Spring in Egypt and the entire region, wherein in the first quarter of 2011, the decrease in the number of tourists was close to $45 \%$. J. Zdanowski (2013) and R. Fiedler 
(2014) also noticed the economic slowdown in Tunisia and Egypt, which took place after the outbreak of the revolution. Moreover, they drew attention to dynamic political events and their deterrent effect on tourists and foreign investors who redirected their capital to more politically stable countries. Fiedler (2014) emphasises that the political unrest in 2012 permanently reduced tourism in Egypt.

In her article The tourism crisis in post-January 25th Egypt (2013), M.S. Hanna focused on the impact of government policy on the tourism sector in 2011-2013. In her work, she emphasised the significant impact of tourism on the economic development of the country and the need to create new jobs in this sector. Investments in infrastructure and the modernisation of monuments must be related to the cash inflow from servicing tourism. In order for the tourism balance to be restored after the revolution of 2011, in her opinion, the Egyptian authorities must not only take care of political and social stability but also deal with the problems of crime, corruption and illegal activities that discourage potential tourists.

In the history of Egypt, terrorist attacks are known to have significantly influenced tourism. In 2004-2006, a series of tragic attacks shocked resorts on the Sinai Peninsula. On 7 October 2004, 34 people were killed and nearly 150 injured in the bombings on the Israeli-Egyptian border. Explosives were planted in places popular with tourists - Taba, Ras al-Shitan and Nuwabi. Two Islamic organisations, one associated with Al Qaeda, confessed to them. Less than a year later, Egypt experienced further attacks in Sharm el-Sheikh. On 23 July 2005, 70 people lost their lives, and more than 150 were injured following the blasts of car bombs. In the triple attack in Dahab on 24 April 2006, which was probably in part caused by Al Qaeda, 23 people were killed, and 62 were injured (Aleksandrowicz, 2008).

By 2015, security conditions had deteriorated to such an extent that Israeli tourists stopped coming to Egypt for 18 months. The shooting down of a plane with Russian tourists that left Sharm el-Sheikh airport on 31 October 2015 again caused tourism stagnation. The suspected cause of the tragedy was a bomb on board the plane, and suspicion largely fell on an airport worker. Russia suspended all flights to Sharm el-Sheikh until Russian officials inspected the airport and met better security standards (Chormański, 1996). Russia and the United Kingdom have restricted flights to Sharm el-Sheikh. However, the Egyptian government, wanting to regain the trust of Russia (who constitute a significant percentage of foreign tourists), lifted the visa requirement for Russians taking holidays in Egypt and introduced the possibility of paying in roubles.

In the following years, other tragic events were aimed directly at tourists who chose Egypt as their destination. On 19 May 2016, the EgyptAir flight 804 departed Paris for Cairo with 66 people on board but crashed over the Mediterranean Sea for unknown reasons. Information about a fire onboard the plane was made public. In 2016 and 2017, tourists were attacked in Hurghada.

In 2018 , tourism revenues had increased sharply by $71 \%$ to USD 4.8 billion. In the first half of 2018, over five million tourists visited Egypt, a $41 \%$ increase compared to the same period in 2017. However, on 28 December 2018, a bomb was planted near a bus carrying Vietnamese tourists. This event caused another stagnation in the tourism market.

Despite the unstable political and economic situation, Egypt is a popular destination among Polish tourists. Relatively low prices compared to other coastal countries, especially Spain, Italy and Greece, favour Egypt. There are several reasons for this. First, Egypt is 
one of the so-called dollar destinations, which means that tour operators organising in this country pay in dollars. If the dollar is lower against the euro, and the zloty has a strong position against both of these currencies, trips to Egypt have desirable prices. It is not without significance that Egypt is a year-round destination - trips in the winter months are trendy when resorts in European countries are closed (Ziółkowska-Weiss, 2016).

\section{Conclusions}

It cannot be denied that the effects of terrorism in tourist areas have a negative economic impact. While terrorist attacks go beyond the control of the most advanced security measures, their impact can be reduced through planning and management practices. Specific destinations and tourist attractions may be under attack, but measures can be taken to avoid or reduce the damage in such cases.

The tourism industry appears to be relatively resilient. In most cases, the sites where a terrorist attack took place had the ability to recover from the devastating effects of terrorism (Sönmez, Apostolopoulos, Tarlow, 1999). Despite the emergence and development of terrorism, tourism continues to expand. It seems appropriate for future academics to investigate the delayed impact of terrorist acts on tourist destinations demand, as many tourism experts have hypothesised that the effects of terrorist acts are only visible in these places for a few weeks after the event itself.

While tourists may avoid risk-related sites, the consequences of catastrophic events for tourist destinations are inevitable and can be profound. Tourism-oriented terrorism can be seen as a catastrophe for a destination, and the resulting events could lead to a major tourism and economic crisis, as is the case in Egypt.

Thus, tourist destinations, especially those prone to political instability and terrorist attacks, should integrate crisis management planning into their overall sustainable development and marketing strategies and provide potential visitors with security. Local governments should implement strategies to help local travel agencies and tourism industry members in a threat to tourists by a terrorist attack. Recommendations include introducing a crisis management plan, creating a tourism crisis management task force, developing a crisis management guide, and cooperating with law enforcement officials.

In order to strive for a constant increase in confidence in the tourism industry in Egypt, the local government should work with the media to emphasise security. Information provided by the media is essential when it comes to security in the tourist reception area. As shown by the research results conducted by the authors of this work, $65 \%$ of Polish respondents participating in the study believe that the media intensifies the threats in Egypt. Therefore, to maintain tourist stability, the media must not exacerbate panic among tourists in a situation of political tension but only play down possible local conflicts.

Another practical implication of the fight against terrorism is discussions on this subject which should be held regularly at international conferences and seminars.

H.A.H. Esmail (2016) does not doubt that the promotion of tourism is one of the main strategies leading to the economic growth of the tourism sector, contributing to community development and poverty reduction in developing countries. Therefore, she proposes that governments worldwide set up regional funds whose activities will contribute to the fight against terrorism, the exchange of information and cross-border investigations between countries. Both the government and other social groups interested in promoting tourism, 
both domestic and international, should have a far-reaching policy in dealing with terrorism that will guarantee tourism development in a given region.

The sad fact is that terrorism and tourism have become inextricably linked. Accepting the permanence of this relationship may help future researchers understand and mitigate the impact of terrorism on tourism demand and the economic and socio-cultural quality of life. The relationship between tourism and terrorism is undeniable in the modern era due to the industry's strength, information flows and globalisation. Tourists are easy targets for terrorists. Acts of terrorism will never be predictable or avoidable. Fortunately, these are relatively rare cases. People want to travel and are likely to choose tourist destinations in which there have been terrorist attacks in the past, as shown by the research results presented in this study.

\section{References}

Abdou, D.S., Zaazou, Z. (2013). The Egyptian Revolution and post-Socio-economic impact. Topics in Middle Eastern and African Economies, 15, 92-115.

Akman, N. (2007). W prawdziwym islamie terroryzm nie istnieje. In: E. Capana (ed.), Terroryzm. Zamachy samobójcze. Muzutmański punkt widzenia. Warszawa: Wydawnictwo Akademickie DIALOG.

Aleksandrowicz, T. (2008). Terroryzm międzynarodowy. Bezpieczeństwo wewnętrzne. Podręcznik akademicki. Warszawa: Wydawnictwo Akademickie i Profesjonalne.

Aly, Y.H., Strazicich, M.C. (2000). Terrorism and Tourism: Is the Impact Permanent or Transitory? Time Series Evidence from Egypt and Israel. Working Paper No. 2010, USA: College of Business and Administration, University of Central Florida.

Barber, B.R. (2004). Dżihad contra Mc Świat. Warszawa: Muza SA.

Choromański, R. (red.). (1996). Almanach wiedzy powszechnej. Warszawa: Skrzydła.

Duda, D. (2002). Terroryzm islamski. Kraków: Wydawnictwo Uniwersytetu Jagiellońskiego.

Esmail, H.A.H. (2016). Impact of Terrorism and instability on the tourism industry in Egypt and Tunisia after Revolution. The Business and Management Review, 7(5), 469-475.

Fiedler, R. (2014). Arabska Wiosna - szanse i wyzwania dla polityki USA wobec Bliskiego Wschodu. Przeglad Politologiczny, 1, 33-49.

Fielding, D., Shortland., A. (2010). How do tourists react to political violence? An empirical analysis of tourism in Egypt. DIW Discussion Papers, 1022, Berlin: Deutsches Institut für Wirtschaftsforschung (DIW).

Hanna, M.S. (2013). The Tourism Crisis in post-January 25th Egypt. Cairo: The American University in Cairo.

Isaac, R. (2021). Badanie rozpoznawcze: Wpływ terroryzmu na postrzeganie ryzyka. Analiza niemieckich zachowań i postaw rynkowych wobec Egiptu. Planowanie i Rozwój Turystyki, 18(1), 25-44.

Kacprzyński, A. (2016). Egipska turystyka - studium. Wrocław.

Kuczyński, M. (2001). Krwawa Europa. Konflikty zbrojne i punkty zapalne w latach 1990-2000. Warszawa: Dom Wydawniczy Bellona.

Marciniak, M., Dłużewska, A. (2015). Wpływ Wiosny Arabskiej na turystykę w Egipcie. Turystyka Kulturowa, 9, 38-53.

Nizioł-Celewicz, M. (2006). Międzynarodowe stosunki polityczne. Lublin: Wydawnictwo Uniwersytetu Marii Curie-Skłodowskiej.

Pizam, A., Smith, G. (2000). Tourism and Terrorism: A Historical Analysis of Major Terrorism Acts and Their Impact on Tourism Destinations. Tourism Economics, 6(2), 123-138.

Polyzos, S., Papadopoulou, G., Xesfingi, S. (2021). Examining the link between terrorism and tourism demand: the case of Egyp. Journal of Policy Research in Tourism, Leisure \& Events. Taylor\&Francis Online. doi: 10.1080/19407963.2021.1904965 
Pospiszyl, I. (2008). Patologie społeczne. Warszawa: Wydawnictwo Naukowe PWN.

Rapoport, D.C. (2004). The Four Waves of Modern Terrorism. In: S.M. Chermak, J.D. Freilich (eds.), Transnational Terrorism. Londyn, Nowy York: Routledge.

Sönmez, S., Apostolopoulos, Y., Tarlow, P. (1999). Tourism in Crisis: Managing the Effects of Terrorism. Journal of Travel Research, 38(1), 13-18.

Wojciechowski, S. (2011). Terroryzm na początku XXI wieku. Pojęcie, istota i przyczyny zjawiska. Bydgoszcz: Oficyna Wydawnicza Branta.

Zdanowski, J. (2013). Znaczenie Arabskiej Wiosny. Krakowskie Studia Bliskowschodnie, 3, 13-32.

Ziółkowska-Weiss, K. (2016). Zachowania konsumenckie Polaków korzystających z oferty polsko-egipskich biur podróży w Szarm el-Szejk. Prace Komisji Geografii Przemystu Polskiego Towarzystwa Geograficznego, 30(4), 102-118.

Kamila Ziółkowska-Weiss, PhD, Pedagogical University of Krakow, Institute of Geography, Department of Tourism and Regional Research. She studied law and cultural studies at the Jagiellonian University - specialising in Mediterranean studies. She is also a geography graduate with the basics of entrepreneurship at the Pedagogical University of Krakow. She completed post-graduate studies at Cracow University of Economics in the field of international tourism management. In 2015, she defended her doctoral thesis with honours, thus obtaining a PhD in Earth Sciences. Since 2012, she has been working in the Department of Tourism and Regional Research of the Pedagogical University of Krakow, teaching, among others, "Tourism in the United States of America". Active tour leader. Author of several dozen academic publications. The main academic interests are the Polish community in North and South America, cultural tourism and national minorities in Poland and North America.

ORCID: https://orcid.org/0000-0001-6575-5314

\section{Address:}

Uniwersytet Pedagogiczny im. Komisji Edukacji Narodowej w Krakowie

Instytut Geografii

Katedra Turystyki i Badań Regionalnych

ul. Podchorążych 2

30-084 Kraków, Polska

e-mail: kamilazw@up.krakow.pl

Emilia Pieron, BA, Pedagogical University of Krakow, Institute of Geography, Department of Tourism and Regional Research. She received a bachelor's degree from the Pedagogical University of Krakow. Currently, she is a graduate student at the above-mentioned university, continuing education in the field of Tourism and Recreation. She managed to obtain a postgraduate diploma in the field of Preparation for the teaching profession, which will allow her to work with young people and transfer the professional knowledge gained during five-year studies. In addition, she is a horse riding instructor and she is interested in the culture of the Middle East.

ORCID: https://orcid.org/0000-0003-2661-1312

\section{Address:}

Uniwersytet Pedagogiczny im. Komisji Edukacji Narodowej w Krakowie

Instytut Geografii

Katedra Turystyki i Badań Regionalnych

ul. Podchorążych 2

30-084 Kraków, Polska

e-mail: emka961234@interia.pl 
Spis treści

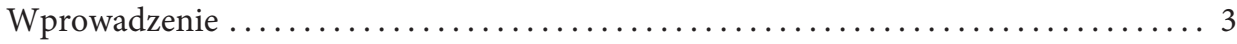

Marcin Olszewski

Scientists' attitudes towards academic entrepreneurship: the results of an empirical

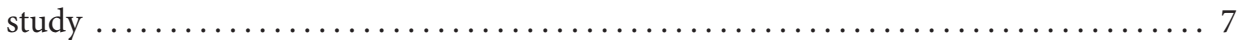

Jacek Rudewicz, Krzysztof Sala

New professional competencies in the era of WEB 2.0 and 3.0

and the dissemination of ICT

WiTOLD WARCHOLIK

Uczelnia - nie-miejsce? Poziom wiedzy społeczności akademickiej o uniwersytecie

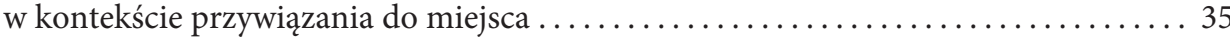

Anna Mazurkiewicz

Młode osoby a sytuacja na rynku pracy w województwie podkarpackim

JoANNA ŚWIĘTONIOWSKA

Przedsiębiorczy gracz - jak mechanizmy grywalizacji motywują do nauki uczniów w szkole średniej?

EWA BADZIŃSKA

Experiential and result-driven entrepreneurship education: evidence from

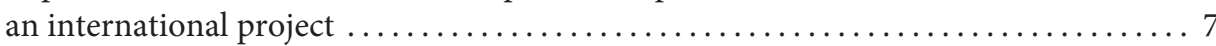

Pawee Marek Woroniecki

Prawne uwarunkowania nauczania przedsiębiorczości

$\mathrm{w}$ polskim systemie oświaty. . . . . . . . . . . . . . . . . . . . . . 90

RoBert Majkut

Charakterystyka uwarunkowań instytucjonalnych wspierania innowacyjności

w Austrii ze szczególnym uwzględnieniem systemu edukacyjnego . . . . . . . . . . . . 104

Dorota OKrasińsKa

Kontinuum wartości pedagogicznych - metody i narzędzia

na przykładzie modelu greckiego w warunkach zmienności - analiza kognitywna . 115

ZBIGNIEW CHODKOWSKI

Wpływ środowiska na motywację do wyboru studiów przez studentów rzeszowskich

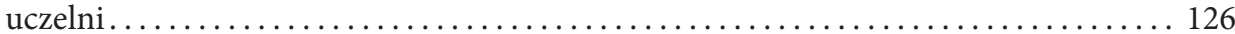

Anita Kulawiak

Postawy przedsiębiorcze młodzieży w najmniejszych miastach regionu łódzkiego . . 140

Jacek Brdulak, Ewelina Florczak, Tomasz Gardziński

Prospołeczność w gospodarce jako czynnik zmian współczesnej ekonomii........ 153

Dorota Murzyn

Social entrepreneurship and selected elements of the entrepreneurship ecosystem. . 165 
Sebastian Kubala, Chrystian Firlej

Self-sufficiency in cereal and potato production in Central and Eastern Europe:

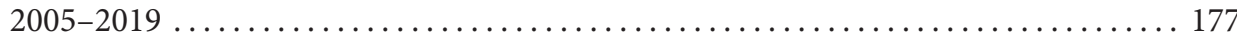

Gabriela Czapiewska

Integration into agricultural producer groups as a manifestation of rural entrepreneurship

Mateusz ĆwikŁa

The delimitation of functional areas in Świętokrzyskie Voivodeship (Poland) concerning social, financial and economic as well as spatial and infrastructural criteria ....... 203

Magdalena Lesiak

Istota analizy wskaźnikowej - ujęcie edukacyjne. 220

Magdalena WierCiOCH

The influence of the socio-demographic characteristics of the young on mobile telephone payment usage levels

Kamila ZióŁkowska-Weiss, Emilia Pieron

Assessment of the impact of terrorism on tourism in the 21st century:

the example of Egypt. 